\title{
Perbedaan Kadar Glukosa, Karotenoid dan Biomassa Alang-Alang (Imperata cylindrica L. Beauv) yang Tumbuh di Daerah Ternaungi di Kec. Kunduran Blora dan Ungaran Timur Semarang
}

\section{Glucose Content Differences, Carotenoids and Biomass Plants That Grow Alang-Alang (Imperata cylindrica L. Beauv) in Shaded Areas in Subdistrict Kunduran Originating Blora and East Ungaran Semarang District}

\author{
Dhitya Arlan Bayu Martha ${ }^{1 *}$, Erma Prihastanti ${ }^{2}$, Sri Haryanti ${ }^{2}$ \\ ${ }^{1}$ Program Studi Biologi, Departemen Biologi, Fakultas Sains dan Matematika, Universitas Diponegoro \\ ${ }^{2}$ Departemen Biologi, Fakultas Sains dan Matematika, Universitas Diponegoro \\ Jl. Prof. Soedarto, SH, Tembalang, Semarang \\ *Email : arlan.bayu@yahoo.com
}

Diterima 1 Juni 2016 / Disetujui 20 Agustus 2016

\begin{abstract}
ABSTRAK
Tanaman alang-alang banyak dimanfaatkan sebagai bahan baku industri jamu dan obat terutama rhizomenya. Kualitas rhizome tanaman alang-alang dipengaruhi oleh berbagai faktor salah satunya adalah lingkungan tumbuhnya. Tujuan penelitian ini untuk mengetahui perbedaan kadar glukosa, karotenoid dan biomassa tanaman alang-alang yang tumbuh pada daerah ternaungi di Kabupaten Blora dan Kabupaten Semarang. Sampel tanaman diambil dari lokasi di daerah Kabupaten Blora dan Semarang dengan 10 ulangan. Metode pengukuran kadar glukosa dan karotenoid dilakukan dengan menggunakan alat UV-Spektrofotometer. Pengukuran Biomassa tanaman alang-alang meliputi berat basah dan berat kering tanaman. Analisis data menggunakan Independent $T$ - Test pada taraf kepercayaan $95 \%$ dengan software SPSS versi 16 . Kadar karotenoid dan glukosa pada rhizome tanaman alang-alang yang berasal dari Kabupaten Blora yaitu 0,8817 ppm dan 2,871 ppm dan biomassa (berat basah 10,98 gram dan berat kering 2,81 gram di Semarang. Kadar Karotenoid dan glukosa pada rhizome tanaman alang-alang yang berasal dari Kabupaten Semarang yaitu 0,7966 ppm dan 2,0686 ppm. Hasil Penelitian menunjukkan bahwa kadar glukosa dan karotenoid tanaman alang-alang dari Kabupaten Blora dan Semarang tidak berbeda secara signifikan namun Biomassa tanaman alang-alang berbeda secara signifikan.
\end{abstract}

Kata kunci : Tanaman alang-alang, karotenoid, glukosa, biomassa

\begin{abstract}
Reed (Imperata cylindrica Beauv) are used as industrial raw materials and medicinal herbs especially it's rhizome . Quality reed rhizome plants is influenced by various factors one of which is the growth environment . The purpose of this study to determine differences in glucose contents, carotenoid contents and biomass of reed that grow in shaded areas in Semarang and Blora regency. Plant samples were taken from locations in the area of Semarang and Blora regency with 10 replications. Measurement of glucose content and carotenoids were performed using an UV - spectrophotometer. Biomass measurements reed plants done by dry weight of the plant . Plant dry weight was measured using scales. Data analysis using Independent T - Test at $5 \%$ confidence level with SPSS software version 16. Carotenoid content and glucose on reed rhizome plants derived from the Blora regency is $0.8817 \mathrm{ppm}$ and 2,871 ppm. Biomass ( wet weight of 10.98 grams and 2.81 grams dry weight ). Carotenoids and glucose content of the reed rhizome plants derived from Semarang regency is $0.7966 \mathrm{ppm}$ and $2.0686 \mathrm{ppm}$. The results of the data analysis results show that the glucose content, carotenoids, reeds from Blora and Semarang regency is not have a significant difference, but Biomass reeds from Blora and Semarang regency is significant difference.
\end{abstract}

Keywords: reed plants, carotenoid content, glucose content, biomass 


\section{PENDAHULUAN}

Alang-alang atau Imperata cylindrica $\mathrm{L}$. Beauv merupakan tanaman rumput yang hidupnya liar dan dapat hidup di tanah basah (lembab) maupun di tanah yang kering (Atien, 2008). Jika dilihat dari segi ekonomi ,tanaman alang-alang mempunyai beragam manfaat yaitu sebagai pakan ternak, bahan baku jamu, industri dalam pembuatan makanan dan lain-lain. Namun demikian alang-alang juga merupakan gulma yang dapat mengeluarkan senyawa alelopati, sehingga dapat menghambat pertumbuhan tanaman lain yang tumbuh di sekitarnya (Moenandir, 1988).

Alang-alang merupakan salah satu tanaman yang dianggap sebagai gulma. Namun demikian, ternyata alang-lang memiliki banyak manfaat yang dapat diambil dari semua bagian tanaman yaitu bagian daun, batang dan rimpang. Bagian daun dan batang dapat digunakan sebagai pakan ternak, kerajinan tangan, pembuatan atap rumah dan campuran pembuatan kertas daur ulang. Bagian rimpang dapat dimanfaatkan untuk pembuatan minuman seperti sirup, dan dapat dipakai sebagai campuran obat. Alang-alang selain sebagai bahan obat dapat juga digunakan sebagai bahan pangan fungsional bagi manusia dan sebagai bahan antioksidan. Alang-alang digunakan sebagai bahan obat, karena mengandung senyawa seperti manitol, sukrosa, glukosa, asam malik, asam sitrat (Atien ,2008).

Tanaman alang-alang tumbuh tersebar di daerah tropik dan sub tropik. Daerah sub tropik meliputi Afrika, Eropa bagian Selatan, Afganistan, Turkestan, Srilangka, Malaysia, India, Cina, Australia dan negara bagian Florida, sedangkan daerah tropis terdapat di Indonesia (Surwadjoko, 1979). Alang-alang adalah tanaman tahunan yang cocok tumbuh di bawah sinar matahari.

Mengingat banyaknya manfaat dari tanaman alang-alang ini, maka sebagian pabrik industri, terutama industri di daerah Jawa Tengah berusaha mengoptimalkan manfaat dari alangalang. Banyak industri di Jawa Tengah memanfaatkan alang-alang sebagai produk obat. Namun dengan terbatasnya bahan baku dan meningkatnya jumlah permintaan, maka banyak pabrik- pabrik industri yang kesulitan dalam mendapatkan bahan untuk memenuhi produksi. Sebagai usaha dalam memenuhi permintaan produk, maka mereka harus menyetok bahan baku dengan cara membudidayakan alang-alang sendiri.

Jawa Tengah, khususnya di Kabupaten Blora dan Kabupaten Semarang merupakan daerah yang berpotensi sebagai penghasil alang-alang. Kabupaten Blora merupakan wilayah dengan ketinggian 30 - $500 \mathrm{~m}$ dpl. Sedangkan Ungaran merupakan wilayah Kabupaten Semarang dengan ketinggian berkisar pada 500-2000m (dpl). Berdasarkan perbedaan tempat pertumbuhan alang-alang inilah, maka penulis ingin meneliti dan menganalisis perbedaan biomassa, kandungan glukosa dan karotenoid alang- alang yang berasal dari tempat yang berbeda.

\section{METODE PENELITIAN}

Penelitian ini dilaksanakan pada bulan Juli 2012 sampai Desember 2012 di Laboratorium Biologi Struktur dan Fungsi Tumbuhan MIPA Universitas Diponegoro Semarang dan Laboratorium Nutrisi Pakan Ternak Peternakan Universitas Diponegoro. Bahan yang digunakan dalam penelitian adalah rimpang alang-alang yang tumbuh di daerah ternaungi yang berasal dari Kabupaten Blora dan Kabupeten Ungaran.

\section{Pengambilan Sampel Alang-Alang}

Alang-alang yang akan diambil adalah alang-alang yang tumbuh pada daerah yang ternaungi yang berasal dari Kabupaten Blora dan Kabupaten Semarang.

\section{Pengambilan Rimpang dan Pembuatan Simplisia Alang-Alang}

Simplisia alang-alang didapatkan dari dua daerah tersebut yaitu dari Kabupaten Blora dan Kabupaten Semarang. Mula-mula rimpang dicuci dengan tujuan untuk membersihkan kotoran berupa tanah yang masih menempel pada rimpang. Proses setelah pencucian adalah pengeringan, yaitu dengan cara dioven dengan suhu $60^{\circ} \mathrm{C}$ selama $3 \mathrm{x}$ 24 jam. Setelah pengeringan rimpang tersebut kemudian dilakukan proses penggilingan dengan 
alat berupa blender. Penggilingan dengan blender bertujuan untuk menghaluskan rimpang supaya menjadi serbuk, proses penggilingan rimpang tidak menggunakan air. Hal ini disebabkan adanya jamur yang akan datang ke bahan karena kandungan air yang tinggi. Hasil penggilingan selanjutnya akan dilakukan dengan proses pengayakan yang bertujuan untuk memisahkan serbuk yang kasar dengan halus.

\section{Biomassa Alang-Alang}

Untuk mengetahui biomassa suatu tanaman dapat dilakukan dengan menghitung berat kering dan berat basah tanaman tersebut. Berat basah di ukur sesaat setelah pengambilan sampel alang-alang. Pengukuran berat kering dilakukan dengan mengeringkan alang-alang selama waktu 48 jam dengan suhu 67C sampai berat yang didapat benar-benar konstan.

\section{Uji Kadar Glukosa Tanaman Alang-alang}

Penetapan total gula menggunakan metode fenol H2SO4. Sebelum melakukan pengujian sampel maka perlu diketahui kurva standar fenol yang digunakan. Pembuatan kurva standar adalah sebagai berikut : $2 \mathrm{ml}$ larutan xilosa standar yang mengandung $0,10,20,30,40$, dan $60 \mu \mathrm{g}$ xilosa masing-masing masukkan ke dalam tabung reaksi, ditambahkan $1 \mathrm{ml}$ larutan fenol 5\% dan dikocok. Kemudian $5 \mathrm{ml}$ H2SO4 ditambahkan dengan cepat. Biarkan selama 10 menit, kocok lalu tempatkan dalam penangas air selama 15 menit. Absorbansinya diukur $480 \mathrm{~nm}$. Pengujian sampel sama dengan pembuatan kurva standar fenol yaitu $2 \mathrm{ml}$ larutan xilosa diganti $2 \mathrm{ml}$ sampel.

\section{Uji Kadar Karotenoid Tanaman Alang-alang}

Mengukur karotenoid dengan pelarut zheksana, etil asetat, dan metanol kualitas p.a. Filtrat disaring dengan menggunakan kertas saring Whattman No 1, kemudian pelarut diuapkan kembali dengan menggunakan rotary evaporator dan sisa pelarut yang mungkin tertinggal diuapkan dengan Labconco Freeze dry. Ekstrak yang diperoleh ditimbang dengan menggunakan neraca analitik, sehingga diperoleh ekstrak kasar nheksana, etil asetat dan metanol (Allen,2003) .

\section{Analisis Data}

Analisis data menggunakan Uji T dan jika ada pengaruh maka diuji lanjut Duncan Multiple Range Test (DMRT) pada taraf kepercayaan 95\% ( Gomez,1995).

\section{HASIL DAN PEMBAHASAN}

\section{Kondisi Lingkungan}

Perbedaan kondisi lingkungan tempat tumbuh tanaman alang-alang di Kabupaten Blora dan Semarang ditunjukkan pada tabel 1. Hasil pengamatan tersebut menunjukkan bahwa intensitas cahaya di Kabupaten Blora dan Semarang hampir sama. Intensitas cahaya merupakan faktor penting dalam proses fotosintesis. Menurut Fitter dan Hay (1991) dalam Pradnyawan, dkk (2004) tanaman yang menggunakan cahaya sebagai sumber energi utamanya, maka intensitas cahaya mempengaruhi proses metabolisme melalui proses fotosintesis yang selanjutnya akan mempengaruhi pertumbuhan dan perkembangan tanaman. Setiap tanaman membutuhkan intensitas cahaya optimum yang spesifik untuk fotosintesis. Tanaman Alangalang tergolong dalam jenis tanaman $\mathrm{C} 4$ yang pada umumnya membutuhkan intensitas cahaya yang tinggi. Menurut Salisbury dan Ross (1995), tanaman C4 membutuhkan intensitas cahaya antara 1000 - 40000 lux.

Jenis tanah di Kabupaten Blora berbeda dengan jenis tanah di Kabupaten Ungaran. Jenis tanah di daerah Blora merupakan tanah entisol (silt) berbeda dengan jenis tanah di daerah Ungaran yang merupakan tanah andosol (sandy silt). Jenis tanah entisol tergolong tanah yang biasanya kurang subur, berbeda dengan tanah andosol yang tergolong tanah yang subur. Perbedaan jenis tanah di Kabupaten Blora dan Semarang dapat dilihat dari perbedaan kandungan hara didalamnya.

Tanah di daerah Blora memiliki kandungan bahan organik dan unsur nitrogen $(\mathrm{N})$ 
lebih rendah dibanding dengan daerah Semarang. Foth (1984), dalam Fujianto (2012) mengatakan bahwa tanah entisol cenderung memiliki tekstur yang kasar, kadar organik dan nitrogen rendah, kemampuan dalam mengikat air rendah, kelembaban dan pHnya selalu berubah dimana kadar asam yang sangat tinggi atau sangat rendah sehingga kurang baik untuk ditanami. Menurut Hardjowigeno, 1993; Anneahira, 2011, dalam Fujianto, 2012 mengatakan bahwa tanah andosol memiliki tekstur gembur, kemampuan mengikat air banyak dan porositas tinggi, sehingga banyak dimanfaatkan untuk perkebunan dan pertanian.

Kadar keasaman $(\mathrm{pH})$ tanah pada sepuluh titik uji di Kabupaten Blora rata-rata sebesar 6,39 sedangkan $\mathrm{pH}$ tanahnya rata-rata sebesar 6,55. Kadar keasaman tanah berkaitan dengan kelarutan unsur hara dalam tanah. Kondisi $\mathrm{pH}$ yang rendah mengakibatkan penurunan kelarutan unsur hara dalam tanah, sehingga absorbsi unsur hara oleh akar tanaman menjadi terhambat sehingga dapat menyebabkan penurunan produktivitas tanaman.

Tabel 1. Hasil Pengamatan Kondisi Lingkungan Tanaman Alang-Alang di Daerah Ternaungi di Kabupaten Blora dan Semarang

\begin{tabular}{lcc}
\hline & Kab. Blora & Kab. Ungaran \\
\hline $\begin{array}{l}\text { Intensitas cahaya (lux) } \\
\text { Curah Hujan rata-rata }\end{array}$ & 7633,3 & 7533,3 \\
(mm/Tahun) & 1496 & 2410 \\
Kelembaban udara rata- & $34-44$ & $61-80$ \\
rata (\%) & $36-41$ & $33-38$ \\
Suhu rata-rata $\left({ }^{0} \mathrm{C}\right)$ & 55 & 65 \\
Kelembaban Tanah (\%) & Entisol & Andosol \\
Jenis Tanah & 6,39 & 6,55 \\
pH tanah & 0,22 & 0,29 \\
N (\%) & 0,26 & 0,32 \\
P (\%) & 0,13 & 0,28 \\
K (\%) & 8 & 11 \\
Rasio C/N & & \\
\hline
\end{tabular}

Kelembaban tanah rata-rata di Kabupaten Blora dan Semarang sebesar $45 \%$ dan $65 \%$. Kelembaban tanah menunjukkan kadar air yang terkandung dalam tanah. Kadar air yang tinggi dapat mengakibatkan intensitas fotosintesis semakin meningkat. Kelembaban tanah juga berpengaruh pada kelarutan unsur hara tanah. Kelembaban tanah yang tinggi mengakibatkan kelarutan unsur hara tanah semakin meningkat sehingga memudahkan akar tanaman dalam menyerap unsur hara tanah tersebut.

Menurut Badan Standarisasi Nasional Indonesia (SNI 19-7030-2004), 2004 kandungan $\mathrm{N}, \mathrm{P}$ dan $\mathrm{K}$ minimum secara berturut-turut yaitu $0,40 \% ; 0,10 \%$ dan $25,5 \%$. Hal ini mununjukkan bahwa kandungan unsur hara $\mathrm{N}, \mathrm{P}, \mathrm{K}$ di Kabupaten Blora dan Semarang dapat dikatakan masih rendah. Kandungan $\mathrm{N}$ yang semakin tinggi akan mendukung pertumbuhan tanaman. Kalium (K) penting untuk perkembangan klorofil, meskipun ia tidak (seperti magnesium) memasuki susunan molekulnya. Daun tanaman yang kekurangan kalium, tepinya menjadi kering dan berwarna kuning coklat sedang permukaannya mengalami klorosis tidak teratur di sekitar tepi daun. Sebagai akibat dari kerusakan ini fotosintesa sangat terganggu dan metabolisme boleh dikatakan menjadi terhenti (Soegiman, 1982) dalam Rukmini (2009). Fosfor berpengaruh menguntungkan pada perkembangan akar, khusus lateral dan akar halus berserabut (Soegiman, 1982).dalam Rukmini (2009). 


\section{Biomassa Tanaman Alang-alang}

Hasil pengukuran biomassa alang-alang yang meliputi berat basah dan berat kering tanaman alang-alang dapat dilihat pada tabel 2 . Tabel tersebut menunjukkan bahwa rata-rata berat basah tanaman alang-alang yang berasal dari
Kabupaten Blora adalah 10,98 g dan rata-rata berat kering sebesar 2,81 g. Hal ini berarti tanaman alang-alang yang berasal dari Kabupaten Blora mengalami penyusutan yaitu sebesar $8,17 \mathrm{~g}$. Penyusutan berat tanaman alang-alang diduga dikarenakan penguapan air yang ada pada alangalang pada saat proses pengeringan dengan oven.

Tabel 2. Hasil Pengukuran Biomassa Alang-Alang yang Tumbuh didaerah Ternaungi di Kabupaten Blora dan Semarang

\begin{tabular}{|c|c|c|c|c|c|}
\hline \multirow{3}{*}{$\begin{array}{c}\text { Lokasi } \\
\text { Pengambilan } \\
\text { Sampel }\end{array}$} & \multirow{2}{*}{\multicolumn{2}{|c|}{$\begin{array}{l}\text { Biomassa Alang-alang } \\
\text { Berat Basah (g/tanaman) }\end{array}$}} & \multirow{3}{*}{$\begin{array}{c}\text { Lokasi } \\
\text { Pengambilan } \\
\text { Sampel }\end{array}$} & \multirow{2}{*}{\multicolumn{2}{|c|}{$\begin{array}{c}\text { Biomassa Alang-alang } \\
\text { Berat Kering (g/tanaman) }\end{array}$}} \\
\hline & & & & & \\
\hline & Blora & Semarang & & Blora & Semarang \\
\hline KW A & 18 & 27 & HP A & 3 & 5,2 \\
\hline KW B & 11,3 & 19 & HP B & 3 & 4,5 \\
\hline KP A & 6,7 & 15,3 & HP C & 2,1 & 3,2 \\
\hline KP B & 8.9 & 34 & SM A & 2,5 & 7 \\
\hline SW A & 15 & 23 & SM B & 5 & 4,5 \\
\hline SW B & 6,3 & 26,5 & SM C & 2 & 4,3 \\
\hline G A & 14,2 & 39 & GA A & 3,1 & 6,7 \\
\hline G B & 11 & 52 & GA B & 2,6 & 8,3 \\
\hline NO A & 9,2 & 36,5 & GA C & 2,2 & 6,3 \\
\hline NOB & 9,2 & 29,5 & B & 2,6 & 5,7 \\
\hline Rata-rata & 10,98 & 30,18 & & 2,81 & 5,57 \\
\hline
\end{tabular}

Keterangan:

KW (Kedungwaru), KP (Kedungpeting), SW (Sendangwates), G (gayam), NO (Ngawen ombo), HP (Hutan penggaron), SM (Sidomulyo), GA (Gedang anak), B (Beji).

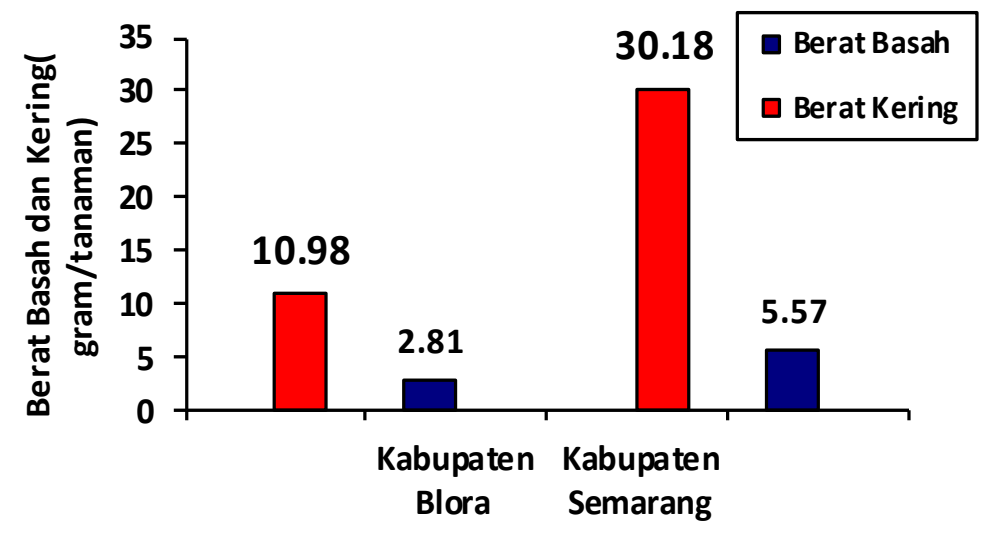

Gambar 1. Histogram Berat Basah dan Berat Kering Tanaman Alang-Alang yang Tumbuh didaerah Ternaungi di Kabupaten Blora dan Ungaran (g)

Penyusutan berat tanaman alang-alang juga terjadi pada tanaman alang-alang yang berasal dari Kabupaten Semarang. Berat basah tanaman alang-alang yang berasal dari Kabupaten Semarang mengalami penurunan berat yang sangat besar yaitu dari berat basah sebesar $30,18 \mathrm{~g}$ menjadi berat kering sebesar $5,57 \mathrm{~g}$. Penurunan berat tanaman alang-alang yang berasal dari Kabupaten Semarang yaitu sebesar 24,61 g. Hal ini menunjukkan bahwa kadar air tanaman alang- 
alang yang berasal dari Kabupaten Semarang lebih besar dari pada tanaman alang-alang yang berasal dari Kabupaten Blora. Hal ini diduga dikarenakan perbedaan tempat tumbuh, iklim, kelembaban, ketinggian tempat tumbuh, dan tingkat curah hujan, dimana kondisi lingkungan di Kabupaten Blora memiliki curah hujan dan kelembaban yang lebih rendah dibandingkan dengan di Kabupaten Semarang. Kandungan air pada tumbuhan akan dipengaruhi oleh faktor lingkungan dan salah satunya adalah kandungan air tanah itu sendiri ((Taiz dan Zeiger, 200).

Berat basah tumbuhan menunjukan keberadaan air, senyawa organik, dan senyawa anorganik (Sarief,1986 dalam Fujianto, 2012). Berat kering tumbuhan terdiri dari senyawa organik, senyawa anorganik, dan komponenkomponen sel (Sutedjo,1994) dalam Fujianto, 2012. Salisbury dan Ross (1995 menjelaskan bahwa bobot basah tanaman menunjukkan aktivitas metabolisme tanaman dan nilai bobot basah ini dipengaruhi oleh kadar air jaringan, unsur hara dan hasil metabolisme.

\section{Kadar Karotenoid Tanaman Alang-Alang}

Hasil pengukuran kadar karotenoid rizhome alang-alang yang berasal dari Kabupaten Blora dan Kabupaten Semarang dapat dilihat pada tabel 3. Tabel 3 menunjukkan hasil pengukuran kadar karotenoid rizhome alang-alang yang berasal dari Kabupaten Blora dan Kabupaten Semarang. Dari tabel diatas dapat dilihat hasil pengukuran rata-rata kadar karotenoid tanaman alang-alang yang berasal dari Kabupaten Blora sebesar 0,8817 ppm, dan kadar tanaman alangalang yang berasal dari Kabupaten Semarang sebesar 0,7966 ppm. Dari data diatas terlihat bahwa kadar karotenoid tanaman alang-alang yang berasal dari Kabupaten Blora lebih banyak dibandingkan dengan tanaman alang-alang yang berasal dari Kabupaten Semarang.

Tabel 3. Hasil Pengukuran Kadar Karotenoid (ppm) Alang-alang yang Tumbuh didaerah Ternaungi di Kabupaten Blora dan Semarang

\begin{tabular}{cccc}
\hline \multicolumn{2}{c}{ Kabupaten Blora } & \multicolumn{2}{c}{ Kabupaten Semarang } \\
\hline Kedungwaru A & 0,965 & Hutan penggaron A & 0,421 \\
Kedungwaru B & 0,774 & Hutan penggaron B & 0,421 \\
Kedungpeting A & 0,628 & Hutan penggaron C & 0,720 \\
Kedungpeting B & 0,666 & Sidomulyo A & 1,984 \\
Sendang wates A & 0,544 & Sidomulyo B & 1,049 \\
Sendang wates B & 0,988 & Sidomulyo C & 0,666 \\
Gayam A & 1,348 & Gedang anak A & 0,705 \\
Gayam B & 1,088 & Gedang anak B & 0,682 \\
Ngawen ombo A & 0,935 & Gedang anak C & 0,544 \\
Ngawen ombo B & 0,881 & Beji & 0,774 \\
\hline Rata-rata & 0,8817 & & 0,7966 \\
\hline
\end{tabular}

Hasil analisa uji $\mathrm{T}$ menunjukan bahwa kadar karotenoid tanaman alang-alang yang berasal dari Kabupaten Blora dan Kabupaten Semarang tidak berbeda nyata. Hal ini diduga dikarenakan pengaruh dari faktor lingkungan yaitu tingkat intensitas cahaya. Johnson and An (1991) dan Albrecht and Sandmann (1994) dalam Kurniawan (2010) mengemukakan bahwa cahaya merupakan salah satu faktor penting dalam biosintesis karotenoid. Menurut Bramley (2002) dalam Kurniawan (2010) peran cahaya tersebut adalah untuk meningkatkan aktivitas enzim yang berperan dalam biosintesis karotenoid. Tingkat intensitas cahaya di Kabupaten Blora dan Semarang tidak berbeda jauh atau bisa dikatakan relatif sama, sehingga proses hasil fotosintesis juga 
tidak berbeda jauh atau relatif sama. Salah satu senyawa metabolit sekunder yang dihasilkan dari proses metabolism lebih lanjut ini adalah berupa karotenoid.

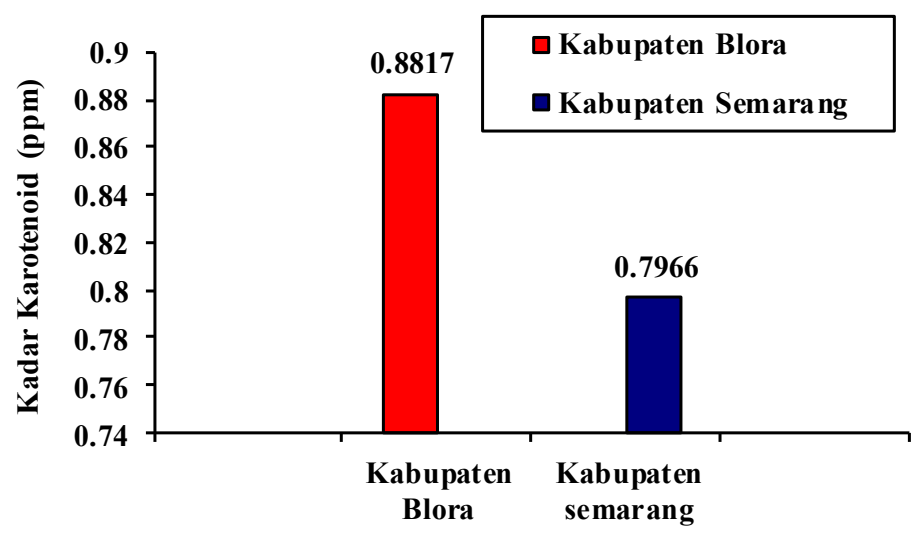

Gambar 2. Histogram Kadar Karotenoid Tanaman Alang-alang yang Tumbuh didaerah Ternaungi di Kabupaten Blora dan Semarang (ppm)

\section{Kadar Glukosa Tanaman Alang-Alang}

Hasil pengukuran Kadar Glukosa rizhome alang-alang yang berasal dari Kabupaten Blora dan Kabupaten Semarang dapat dilihat pada tabel 4. Tabel tersebut menunjukkan pengukuran rata-rata kadar glukosa tanaman alang-alang yang berasal dari Kabupaten Blora sebesar 2,871 ppm, dan kadar glukosa tanaman alang-alang yang berasal dari Kabupaten Semarang sebesar 2,068 ppm. Data diatas terlihat bahwa kadar glukosa tanaman alangalang yang berasal dari Kabupaten Blora lebih besar dibandingkan dengan tanaman alang-alang yang berasal dari Kabupaten Semarang.

Tabel 4. Hasil Pengukuran Kadar Glukosa (ppm) Alang-alang yang Tumbuh didaerah Ternaungi di Kabupaten Blora dan Semarang

\begin{tabular}{cccc}
\hline \multicolumn{2}{c}{ Kabupaten Blora } & \multicolumn{2}{c}{ Kabupaten Semarang } \\
\hline Kedungwaru A & 2,322 & Hutan penggaron A & 1,998 \\
Kedungwaru B & 1,654 & Hutan penggaron B & 1,670 \\
Kedungpeting A & 4,109 & Hutan penggaron C & 2,178 \\
Kedungpeting B & 1,770 & Sidomulyo A & 1,891 \\
Sendang wates A & 2,376 & Sidomulyo B & 2,174 \\
Sendang wates B & 5,222 & Sidomulyo C & 1,346 \\
Gayam A & 3,696 & Gedang anak A & 1,594 \\
Gayam B & 2,035 & Gedang anak B & 1,738 \\
Ngawen ombo A & 4,422 & Gedang anak C & 3,055 \\
Ngawen ombo B & 1,104 & Beji & 3,042 \\
\hline Rata-rata & 2,871 & & 2,068 \\
\hline
\end{tabular}

Hasil analisa uji $\mathrm{T}$ menunjukan bahwa kadar glukosa tanaman alang-alang yang berasal dari Kabupaten Blora dan Kabupaten Semarang tidak berbeda nyata, meskipun pada Tabel 4.4 menunjukkan nominal yang berbeda. Hal ini diduga dikarenakan pengaruh dari tingkat 
intensitas cahaya. Intensitas cahaya yang tinggi maka proses fotosintesis berjalan optimal. Tingkat intensitas cahaya di Kabupaten Blora dan Semarang tidak berbeda jauh atau bisa dikatakan relatif sama, sehingga proses hasil fotosintesis juga tidak berbeda jauh atau relatif sama. Salah satu senyawa yang dihasilkan dalam proses ini adalah glukosa, sehingga kadar glukosa rhizome alangalang di Kabupaten Blora dan Semarang tidak berbeda jauh (Gambar 6). Intensitas cahaya yang tinggi membuat tanaman $\mathrm{C} 4$ mengoptimalkan peran stomata, kloroplast dan organel sel lainnya untuk melakukan proses fotosintesis, sehingga produksi metabolit primer (karbohidrat, protein, serat) akan lebih optimal (Fujianto, 2012). Intensitas cahaya yang rendah dapat menurunkan karbohidrat yang terbentuk (Chaturvedi et al., 1994 dalam Fujianto, 2012).

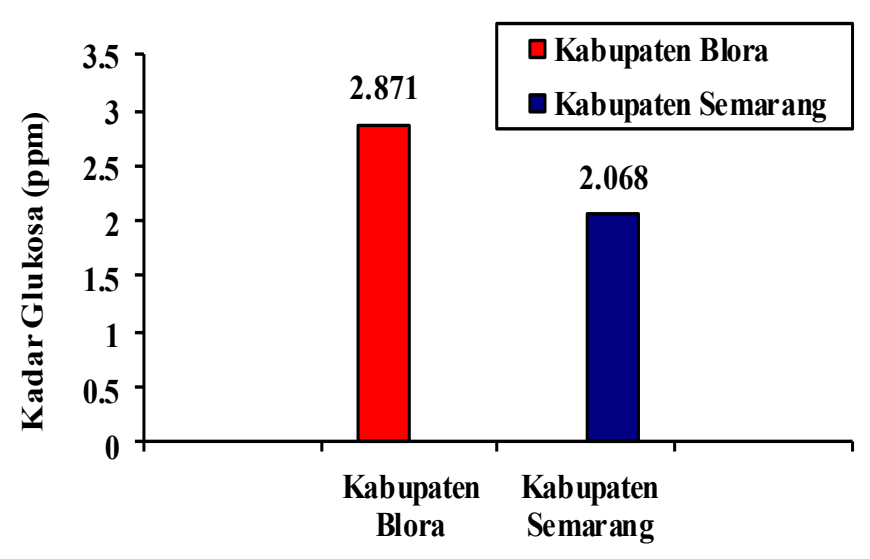

Gambar 3. Histogram Kadar Glukosa Tanaman Alang-alang yang Tumbuh didaerah Ternaungi di Kabupaten Blora dan Semarang (ppm)

\section{SIMPULAN}

Kadar karotenoid dan glukosa tanaman alang - alang (Imperata cylindrica L Beauv) yang tumbuh pada daerah ternaungi di Kabupaten Blora dan Semarang tidak berbeda secara singnifikan, namun biomassa dari kedua daerah tersebut menunjukkan hasil yang berbeda nyata.

\section{DAFTAR PUSTAKA}

Ariani, Didi A. dan Sari J. 2005. Pelatihan Pemanfaatan Akar Alang - Alang Menjadi Sirup dan Bahan Campuran Pembuatan Kertas Daur Ulang di Desa Bandar Khalifah. Universitas Negeri Medan. Medan.

Atien, S. 2008. Apotek Hidup Tanaman Rempah Rempah dan Tanaman Liar. Bandung. Yrama Widya.

Desiana. 2000. Ekstraksi Pigmen Karotenoid dari Limbah Udang Windu.IPB. Bogor.
Dutta, D., Chaudhuri, U.R.and Chakaborty. R. 2005. Structure Health Benevit Antioxidant Property and Processing of Carotenoid. Jadavpun University. India.

Fujianto. 2012. Perbedaan Kandungan Glokosa, Karotenoid dan Biomassa Tanaman Alang-alang (Imperata cylindrica) Yang Tumbuh di Daerah Tidak Ternaungi di Kabupaten Blora dan Ungaran. Skripsi Jur. Biologi MIPA Undip Semarang.

Gardner, F.P., Pearce R.B, and Mitchell, R.L.1991. Diterjemahkan oleh Susilo, $\mathrm{H}$ dan Subiyanto. Fisiologi Tanaman Budidaya. Penerbit Universitas Indonesia (UI Pers). Jakarta.

Gomez KA, and Gomez AA. 1995. Prosedur Statistik untuk Penelitian Petanian. Edisi Kedua. (Diterjemahkan oleh Endang Sjamsuddin dan Yuspika S Baharjsah) Jakarta. Universitas Indonesia Press. 
Harjadi. 1997. Kimia Dasar 1. IPB. Bogor.

Heiskanen, 2006. BIOMASS ECV REPORT.ww.fao.org/GTOS/doc/ECVs/T 12-biomass-standards-report-v01.doc

Heriyanto dan Limantara, L. 2009.Produksi Karotenoid oleh Khamir Roduntula sp. Eksplanasi Volume 4 nomor $7 \mathrm{hlm} 1-3$.

Hitchcock III, H.C. and J.P. McDonnell, 1979. Biomass measurement: a synthesis of the literature. Proc. For. Inventory Workshop, SAF-IUFRO. Ft. Collins, Colorado: 544595.

Hopkins WG and Huner NPA. 2004. Introduction to Plant Physiology. Hoboken: John Wiley \& Sons. Hal. 17-29.

Howard R. L, Abotsi E, Jansen Van Renssburg E.L. and Howard S. 2003.Lingnocellus Biotecnology : Issue of Bioconversion and Enzyme Production. Http://www.academicjournals.org/AJB.Di akses 15 Maret 2012.

Jatmiko. 2004. Studi Pembuatan Sirup Akar Alang- alang (Imperata cylindrical). Skripsi yang tidak dipublikasikan. Medan: Universitas Sumatra Utara: 16-25.

Irawan, M.dan Anwari. 2007. Glukosa dan metabolism Energi. Sports Science Brief Vol. 01, No. 06.

Kathleen, S. 2000. Rehabilitasi Padang Alang Alang Menggunakan Agroforesty dan Pemeliharaan Permudaan Alam. Bogor.

Kurniawan, M. 2010. Kandungan Klorofil, Karotenoid dan Vitamin C Pada Beberapa Spesies Tumbuhan Akuatik. Buletin Anatomi dan Fisiologi Vol. XVIII, No. 1, Maret. Universitas Diponegoro.

Mursito, B. 2000. Ramuan Tradisional Untuk Kesehatan Anak. Jakarta: Penebar Swadaya.

Moenandir, J. 1988.Persaingan Tanaman Budidaya dengan Gulma. Jakarta. Rajawali.
Pradnyawan Sri Wahyudyana Hurip, dkk. 2004. Pertumbuhan, Kandungan Nitrogen, Klorofil dan Karotenoid Daun Gynura procumbens (Lour) Merr. Pada Tingkat Naungan Berbeda. Biofarmasi 3 (1): 7-10 ISSN: $1693-2242$

Purnomosidhi. 2000. Reclamation of Imprete Grassland Using Agroforesty. International Centre for Research in Agroforesty Sounthest Asian Regional. Bogor.

Salisbury, F.B dan C.W. Ross. 1992. Fisiologi Tumbuhan Jilid 3. Terjemahan oleh Diar R. Lukman dan Sumaryono. 1995. Penerbit ITR, Bandung.

Salisbury, F.B dan C.W. Ross. 1995. Fisiologi Tumbuhan Jilid 3. Terjemahan oleh Diar R. Lukman dan Sumaryono. 1995. Penerbit ITR, Banding.

Sitompul, S.M dan Guritno B., 1995. Analisis Pertumbuhan Tanaman. Gadjah Mada University Press. Yogyakarta.

Suarni. 2005. Potensi Kandungan Senyawa $\beta$ Karoten beberapa Komoditi sebagai Vitamin A. Balai Penelitian Tanaman. Serellia.

Sudarsono. 2002. Tanaman Obat di Indonesia. Badan Pengawasan Obat dan Makanan Republik Indonesia. Jakarta.

Sutaryo, D. 2009. Penghitungan Biomassa Sebuah Pengantar Untuk Studi Karbon dan Perdagangan Karbon. Wetlands International Indonesia Programme.

Syukur, C. 2004. Temu Putih Tanaman Obat Anti Kanker.Penebar Swadaya. Jakarta.

Surwadjoko. 1979. Standar Kualitas Simplisia. Badan Pengawasan Obat dan Makanan Republik Indonesia. Jakarta.

Warsito, A. 1997. Biokimia.Surakarta : Universitas Muhammadiyah. Surakarta. 